Jurnal Media

Teknik dan

Sistem Industri
Jurnal Media Teknik \& Sistem Industri

Vol. 5 (no. 1) (2021) hal. $1-8$

http://jurnal.unsur.ac.id/JMTSI

\title{
Meminimalisirkan Gagal Antar di Kantor Pos Mojokerto dengan Metode DMAIC
}

\author{
Arelia Sofiana $^{1 *}$, Ekra Sanggala ${ }^{2}$ \\ ${ }^{1,2}$ Logistik Bisnis Politeknik POS Indonesia \\ Jl. Sariasih no 54, Bandung \\ 1*arelsofiana09@gmail.com (Korespondensi) \\ ${ }^{2}$ ekrasanggala@mail.ru
}

\section{Minimizing Delivery Failure at Mojokerto Post Office using the DMAIC Method}

Dikirimkan: 01, 2021. Diterima: 03, 2021. Dipublikasikan : 03, 2021.

\begin{abstract}
Service companies, especially in the logistics sector during the pandemic, are currently very much needed by many people. The increasing demand for package and mail delivery services is increasing day by day, must be balanced with service and timely delivery to the recipient. PT. Pos Indonesia (Persero) Kantor Pos Pemeriksaan (KPRK) Mojokerto 61300 is a company engaged in courier and logistics services which has a target to be able to provide better services for customers. However, the Mojokerto Inspection Post Office (KPRK) still has several problems, including the problem of delivery failure parcels and letters to recipients or what is commonly called the failure of the Standard Delivery Time. The purpose of this research is to minimize the occurrence of delivery failures parcels and letters and to increase Standard Delivery Time. Data obtained from observations, interviews and direct documentation in the field. The method used in this problem is to use the DMAIC method (Define, Measure, Analyze, Improve, Control). The results of the analysis and discussion through several calculations on the check sheet and Pareto diagram, it is known that delivery failed packages and letters for three months amounted to 3,406 items with the highest problem factors being incomplete addresses and moving recipients. To minimize these problems, human resources must be improved and improved.
\end{abstract}

Keywords - Failed Delivery, DMAIC, Standard Delivery Time, KPRK Mojokerto

\begin{abstract}
Abstrak - Perusahaan jasa khususnya bidang logistik pada masa pandemi saat ini sangat dibutuhkan oleh banyak masyarakat. Mewabahnya permintaan jasa pengiriman paket dan surat semakin hari semakin meningkat harus diimbangi dengan pelayanan dan pengiriman tepat waktu kepada penerima. PT. Pos Indonesia (Persero) Kantor Pos Pemeriksaan (KPRK) Mojokerto 61300 merupakan perusahaan bergerak di bidang jasa kurir dan logistik yang memiliki target untuk dapat memberikan pelayanan jasa yang lebih baik bagi pelanggan. Namun Kantor Pos Pemeriksaan (KPRK) Mojokerto masih memiliki beberapa permasalahan diantaranya permasalahan gagal antar kiriman paket dan surat kepada penerima atau biasa disebut ketidakberhasilan Standar Waktu Penyerahan (SWP). Tujuan penelitian ini adalah untuk meminimalisir terjadinya gagal antar kiriman paket dan surat serta meningkatkan Standar Waktu Penyerahan. Data diperoleh dari hasil observasi, wawancara dan dokumentasi langsung di lapangan. Metode yang digunakan dalam permasalahan ini adalah dengan menggunakan metode DMAIC (Define, Measure, Analyze, Improve, Control). Hasil dari analisis dan pembahasan melalui beberapa perhitungan pada check sheet dan diagram pareto maka diketahui gagal antar kiriman paket dan surat selama tiga bulan berjumlah 3.406 item dengan faktor permasalahan tertinggi alamat yang tidak lengkap dan penerima pindah. Untuk meminimalisirkan permasalahan tersebut maka SDM harus dilatih dan ditingkatkan.
\end{abstract}

Kata kunci — Gagal Antar, DMAIC, Standar Waktu Penyerahan, KPRK Mojokerto 


\section{PENDAHULUAN}

PT. POS Indonesia merupakan perusahaan jasa pengiriman barang dan keuangan milik BUMN (Badan Usaha Milik Negara) yang mempunyai jaringan yang sangat luas hingga 4.800 kantor pos online. Jumlah titik layanan (Point of Sales) mencapai 58.700 titik dalam bentuk kantor pos, Agen pos, Mobile Postal Service, dan lain-lain. Kantor Pos Mojokerto dalam sebulan kiriman barang mempunyai ratarata pengiriman 30.000-60.000 paket dan surat yang harus diantar ke penerima dengan berhasil antar. Akan tetapi, dalam pengiriman masih terdapat permasalahan yaitu gagal antar kiriman paket dan surat yang menjadikan alasan-alasan pihak penerima menjadikan gagal antar. Untuk menyelesaikan permasalahan maka melakukan identifikasi masalah dengan menggunakan metode DMAIC

DMAIC adalah pendekatan yang terbukti untuk menghilangkan dan memperbaiki defect dan meningkatkan kualitas yang berkaitan dengan metrik bisnis. DMAIC merupakan salah satu prosedur pemecahan masalah yang dipakai secara luas dalam masalah peningkatan kualitas dan perbaikan proses [1]. DMAIC selalu diasosiasikan dengan aktivitas six sigma, dan hampir semua penerapan six sigma menggunakan pendekatan DMAIC

Tujuan penelitian ini yaitu: Untuk mengetahui faktor-faktor permasalahan yang menyebabkan gagal antar kiriman paket dan surat, mengetahui alasan terbesar dari pihak penerima menjadikan gagal antar kiriman paket dari surat, mengetahui cara perbaikan terhadap gagal antar kiriman paket dan surat.

\section{METOdologi PENELITIAN}

Seperti yang telah dibahas di bagian I, metode yang digunakan untuk menyelesaikan permasalahan gagal antar dengan menggunakan metode DMAIC. Metode DMAIC terdiri dari Define, Measure, Analyze, Improve, Control.

Define merupakan tahap fase pertama dalam menentukan masalah. Define dimulai dengan mengidentifikasikan masalah yang membutuhkan solusi dan diakhiri dengan pemahaman yang jelas tentang ruang lingkup masalah dan bukti dukungan manajemen, yang memberi otoritas proyek untuk bergerak maju melalui komitmen sumber daya [2].

Tahap Measure adalah melakukan pengukuran dengan mengumpulkan data. Tahap measure mengumpulkan data sebanyak mungkin tentang proses saat ini, termasuk statistik dari persyaratan yang ditentukan [3]. Dalam mencari masalah prioritas pada tahap ini yaitu dengan menganalisis menggunakan check sheet dan diagram Pareto. Check sheet adalah sebuah formulir isian untuk mengumpulkan data di lokasi tertentu di mana kejadian terjadi dan dicatat pada waktu terjadinya [4]. Diagram pareto adalah bagan yang berisikan diagram batang dan diagram garis [5].

$$
\text { Analyze dilakukan pencarian akar }
$$
permasalahan yang terjadi. Tahap ini akan menentukan penyebab paling utama dari defect [6].

Pada tahapan improve ini digunakan metode $5 \mathrm{~W}+1 \mathrm{H}$ dalam memperbaiki defect. Dalam merekomendasikan tindakan atau solusi atas masalah dari $5 \mathrm{w}+1 \mathrm{H}$ yaitu pengembangan rencana tindakan merupakan salah satu aktivitas yang penting dalam program peningkatan kualitas Six Sigma [3].

Control merupakan tahap terakhir dari metode DMAIC di mana tahap ini adalah mengimplementasikan solusi dan mengontrol rencana yang sudah dibuat. Tujuan dari tahapan ini adalah untuk menetapkan standarisasi serta mengontrol dan mempertahankan proses yang telah diperbaiki, ditingkatkan dan mencegah potensi permasalahan yang akan terjadi di kemudian hari [7]. Gambar flowchart langkahlangkah dalam proses penelitian gagal antar dapat dilihat pada Gambar I.

Berikut adalah penjelasan dari flowchart langkah-langkah dalam proses penelitian gagal antar antara lain:

1. Studi Lapangan

Tahap pertama yang dilakukan adalah melakukan studi lapangan atau internship.

2. Perumusan Masalah

Tahap kedua adalah perumusan masalah yang ada di dalam perusahaan. Pada tahap ini adalah proses mengamati, menemukan permasalahan dan menganalisa.

3. Studi Literatur

Melakukan studi literatur untuk memahami referensi teori-teori.

4. Tujuan Penelitian

Untuk mengetahui faktor permasalahan yang menyebabkan gagal antar, mengetahui alasan terbesar dari pihak penerima menjadikan gagal antar, serta mengetahui upaya perbaikan terhadap gagal antar.

5. Pengumpulan Data

Data yang diperlukan adalah data gagal antar dan berhasil antar selama tiga bulan. Pada pengumpulan data ini dilakukan dengan cara wawancara dengan pihak terkait seperti manager antaran. Selain wawancara data tersebut diambil dari web atau aplikasi perusahaan terkait. Data gagal antar yang dikumpulkan yaitu resi, dan pengecekan status antaran.

6. Penelitian (Pengelolaan Data)

Tahap ini mengelola data yang sudah ada dengan menggunakan metode DMAIC. DMAIC 
singkatan dari Define, Measure, Analyze, Improve, Control.

7. Pembahasan dan Analisis

Pada tahap ini berisi tentang analisis dan pembahasan terhadap hasil penelitian
Kesimpulan yang berisikan penarikan kesimpulan terhadap pengelolaan data dan saran-saran yang bersifat membangun dan memperbaiki.

8. Kesimpulan

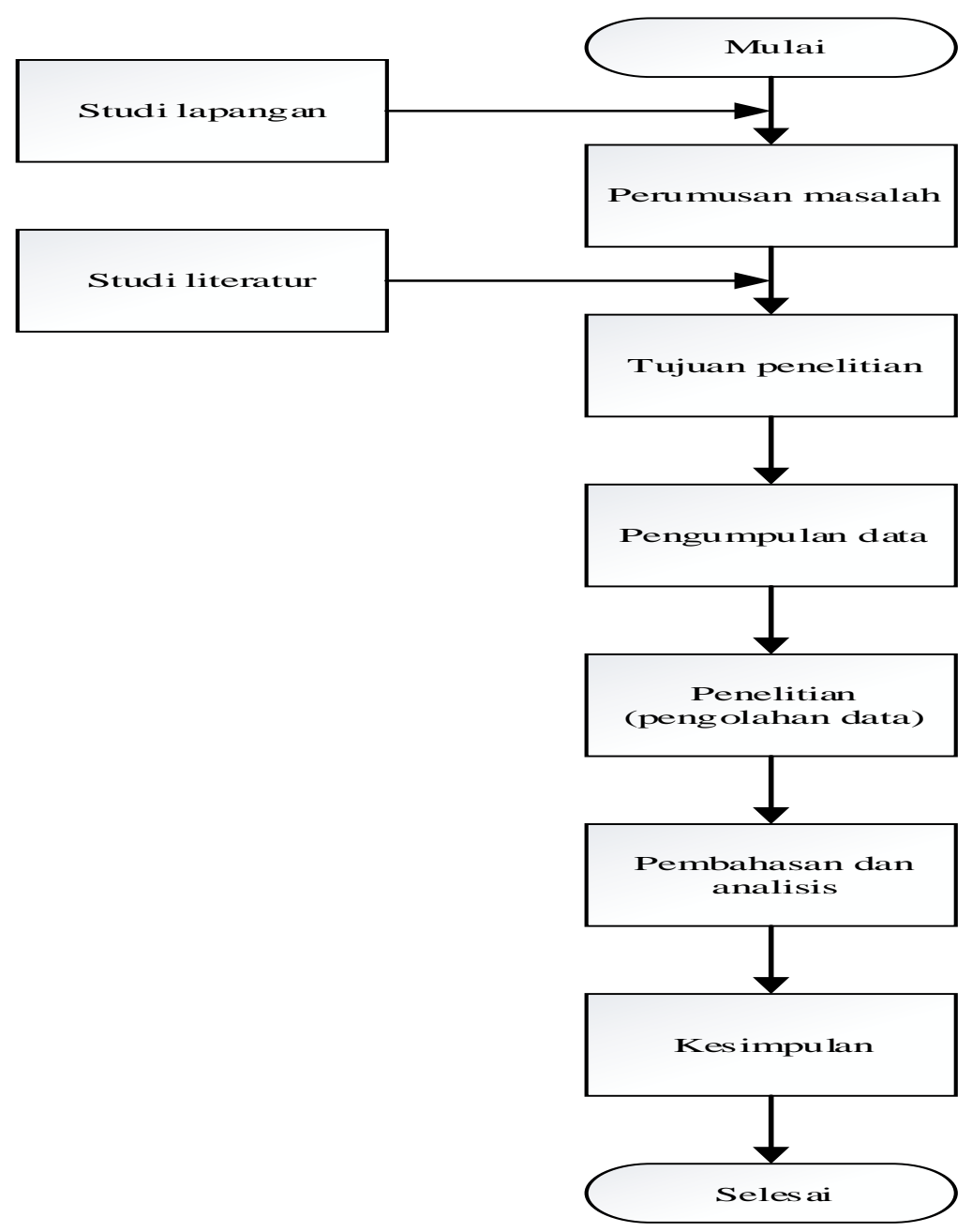

Gambar 1. Flowchart langkah-langkah dalam proses penelitian gagal antar

\section{HASIL PENELITIAN}

Pada bagian ini akan membahas mengenai hasil penelitian faktor-faktor penyebab gagal antar selama tiga bulan dengan menggunakan metode DMAIC.

Define

Tahap Define memastikan bahwa masalah /proses yang dipilih untuk melalui metodologi perbaikan DMAIC terkait dengan prioritas organisasi dan memiliki dukungan manajemen. Define dimulai dengan mengidentifikasik masalah yang membutuhkan solusi dan diakhiri dengan pemahaman yang jelas tentang runag lingkup masalah dan bukti dukungan manajemen, yang memeberi otoritas proyek untuk bergerak maju melalui komitmen sumber daya [2]. Kantor Pos
Mojokerto dalam menjalankan proses kerjanya terdapat permasalahan yang dihadapi yaitu ketidakberhasilan SWP (Standar Waktu Penyerahan) atau yang disebut dengan gagal antar. Gagal antar merupakan suatu permasalahan dimana barang tersebut tidak bisa diteruskan atau dikirimkan ke penerima karena ada beberapa alasan dan barang tersebut dikembalikan ke pengirim. Sehingga keberhasilan SWP yang sudah ditargetkan oleh Kantor Pos Mojokerto tidak sesuai dengan yang diharapkan. Data antaran dalam tiga bulan akhir di tahun 2020 dapat dilihat pada Tabel I. Sedangkan data gagal antar berdasarkan faktor penyebab gagal antar kiriman paket dan surat selama tiga bulan tahun 2020 dapat dilihat pada Tabel II - IX. 


\section{A. Measure}

Pada tahap ini merupakan tahap pengumpulan data kemudian akan diolah sehingga mendapatkan akar penyebab masalah. Mengumpulkan data sebanyak mungkin tentang proses saat ini, termasuk statistik dari persyaratan yang ditentukan [3]. Dari beberapa faktor tersebut akan dicari masalah prioritas dengan menganalisis menggunakan check sheet dan diagram Pareto

TABEL I

DATA ANTARAN DALAM TIGA BULAN TAHUN 2020.

\begin{tabular}{|c|c|c|c|c|c|}
\hline \multirow{2}{*}{ Bulan } & \multirow{2}{*}{$\begin{array}{c}\text { Total } \\
\text { antaran }\end{array}$} & \multicolumn{2}{|c|}{ Status antaran } & \multicolumn{2}{|c|}{$\begin{array}{c}\text { Persentase } \\
\text { Status Antaran }\end{array}$} \\
\hline & & $\begin{array}{l}\text { Berhasi } \\
1\end{array}$ & $\begin{array}{l}\text { Gag } \\
\text { al }\end{array}$ & $\begin{array}{l}\text { Berhasi } \\
1\end{array}$ & $\begin{array}{l}\text { Gag } \\
\text { al }\end{array}$ \\
\hline $\begin{array}{l}28-30 \\
\text { Septe } \\
\text { mber }\end{array}$ & 8.008 & 7.889 & 119 & $\begin{array}{c}98,514 \\
\%\end{array}$ & $\begin{array}{c}1,49 \\
\%\end{array}$ \\
\hline $\begin{array}{l}\text { Oktob } \\
\text { er }\end{array}$ & 58.549 & 57.111 & $\begin{array}{c}1.43 \\
8\end{array}$ & $\begin{array}{c}97,544 \\
\%\end{array}$ & $\begin{array}{c}2,46 \\
\%\end{array}$ \\
\hline $\begin{array}{l}\text { Nove } \\
\text { mber }\end{array}$ & 51.979 & 50.975 & $\begin{array}{c}1.00 \\
4\end{array}$ & $\begin{array}{c}98,068 \\
\%\end{array}$ & $\begin{array}{l}1,93 \\
\%\end{array}$ \\
\hline $\begin{array}{l}1-26 \\
\text { Dese } \\
\text { mber }\end{array}$ & 41.723 & 40.878 & 845 & $\begin{array}{c}97,975 \\
\%\end{array}$ & $\begin{array}{c}2,03 \\
\%\end{array}$ \\
\hline Total & $\begin{array}{c}160.25 \\
9 \\
\end{array}$ & $\begin{array}{c}156.85 \\
3 \\
\end{array}$ & $\begin{array}{c}3.40 \\
6 \\
\end{array}$ & $\begin{array}{c}97,875 \\
\%\end{array}$ & $\begin{array}{l}2,13 \\
\%\end{array}$ \\
\hline
\end{tabular}

TABEL II

DATA GAGAL ANTAR ALAMAT TIDAK LENGKAP

\begin{tabular}{cc}
\hline Bulan & Alamat Tidak Lengkap \\
\hline $28-30$ September & 69 \\
Oktober & 908 \\
November & 620 \\
1-26 Desember & 498 \\
\hline Total & 2.095 \\
\hline
\end{tabular}

TABEL III

DATA GAGAL ANTAR PENERIMA PINDAH

\begin{tabular}{cc}
\hline Bulan & Penerima Pindah \\
\hline $28-30$ September & 23 \\
Oktober & 245 \\
November & 167 \\
1-26 Desember & 119 \\
\hline Total & 554 \\
\hline
\end{tabular}

TABEL IV

DATA GAGAL ANTAR DITOLAK PENERIMA

\begin{tabular}{cc}
\hline Bulan & Ditolak Penerima \\
\hline $28-30$ September & 24 \\
Oktober & 135 \\
November & 162 \\
1-26 Desember & 154 \\
\hline Total & 475 \\
\hline
\end{tabular}

TABEL V

DATA GAGAL ANTAR PENERIMA MENINGGAL DUNIA

\begin{tabular}{cc}
\hline Bulan & $\begin{array}{c}\text { Penerima Meninggal } \\
\text { Dunia }\end{array}$ \\
\hline $28-30$ September & 0 \\
Oktober & 22 \\
November & 6 \\
1-26 Desember & 7 \\
\hline Total & 35 \\
\hline TABEL VI & \\
DATA GAGAL ANTAR RUMAH KOSONG \\
\hline Bulan \\
28 - 30 September \\
Oktober \\
November \\
1-26 Desember \\
Total \\
\hline
\end{tabular}

TABEL VII

DATA GAGAL ANTAR BUNTU

\begin{tabular}{cc}
\hline Bulan & Buntu \\
\hline $28-30$ September & 2 \\
Oktober & 46 \\
November & 21 \\
1-26 Desember & 26 \\
\hline Total & 95 \\
\hline \multicolumn{2}{c}{ TABEL VIII } \\
DATA GAGAL ANTAR SEBAB KAHAR \\
\hline Bulan & Sebab Kahar \\
\hline 28 - 30 September & 1 \\
Oktober & 21 \\
November & 5 \\
1-26 Desember & 7 \\
\hline Total & 34 \\
\hline
\end{tabular}

TABEL IX

DATA GAGAL ANTAR TIDAK MEMENUHI SYARAT PABEAN

\begin{tabular}{cc}
\hline Bulan & $\begin{array}{c}\text { Tidak Memenuhi Syarat } \\
\text { Pabean }\end{array}$ \\
\hline $28-30$ September & 0 \\
Oktober & 26 \\
November & 1 \\
1-26 Desember & 1 \\
\hline Total & 28 \\
\hline
\end{tabular}


Jurnal Media

Teknik dan

Sistem Industri

Setelah mendapatkan data gagal antar, selanjutnya membuat tabel check sheet dan frekuensi permasalahan gagal antar yang ada di Kantor Pos Mojokerto 61300, dapat dilihat pada Tabel X dan XI.

Berdasarkan tabel check sheet dan frekuensi permasalahan faktor penyebab permasalahan di atas bahwa permasalahan yang terjadi yaitu ada 8 buah faktor permasalahan diantaranya alamat yang tidak lengkap, penerima pindah, ditolak penerima, buntu, rumah kosong, meninggal dunia, sebab kahar, dan tidak memenuhi syarat pabean. Setelah menggunakan prinsip pareto dimana persentase kumulatif $80 \%$ masuk ke dalam potential cause dilihat dari tabel 11 frekuensi permasalahan ada dua potential cause yang ditemukan.

TABEL X

CHECK SHEET GAGAL ANTAR

\begin{tabular}{|c|c|c|c|c|c|}
\hline \multirow{2}{*}{$\begin{array}{l}\text { Jenis } \\
\text { gagal } \\
\text { antar }\end{array}$} & \multicolumn{4}{|c|}{ Bulan } & \multirow[b]{2}{*}{$\begin{array}{c}\text { Tota } \\
1\end{array}$} \\
\hline & $\begin{array}{c}28-30 \\
\text { Septemb } \\
\text { er }\end{array}$ & $\begin{array}{c}\text { Oktob } \\
\text { er }\end{array}$ & $\begin{array}{l}\text { Nove } \\
\text { mber }\end{array}$ & $\begin{array}{l}1-26 \\
\text { Dese } \\
\text { mber }\end{array}$ & \\
\hline $\begin{array}{c}\text { Alamat } \\
\text { tidak } \\
\text { jelas }\end{array}$ & 69 & 908 & 620 & 498 & $\begin{array}{c}2.09 \\
5\end{array}$ \\
\hline $\begin{array}{l}\text { Penerima } \\
\text { pindah }\end{array}$ & 23 & 245 & 167 & 119 & 554 \\
\hline $\begin{array}{c}\text { Ditolak } \\
\text { penerima }\end{array}$ & 24 & 135 & 162 & 154 & 475 \\
\hline Buntu & 2 & 46 & 21 & 26 & 95 \\
\hline $\begin{array}{l}\text { Rumah } \\
\text { kosong }\end{array}$ & 0 & 35 & 22 & 33 & 90 \\
\hline $\begin{array}{l}\text { Menging } \\
\text { gal dunia }\end{array}$ & 0 & 22 & 6 & 7 & 35 \\
\hline $\begin{array}{l}\text { Sebab } \\
\text { kahar }\end{array}$ & 1 & 21 & 5 & 7 & 34 \\
\hline $\begin{array}{l}\text { Tidak } \\
\text { memenuh } \\
\text { i syarat } \\
\text { pabean }\end{array}$ & 0 & 26 & 1 & 1 & 28 \\
\hline
\end{tabular}

TABEL XI

FREKUENSI PERMASALAHAN

\begin{tabular}{lccc}
\hline Permasalahan & Frekuensi & Persentase & $\begin{array}{c}\text { Akumulasi } \\
\text { persentase }\end{array}$ \\
\hline $\begin{array}{l}\text { Alamat tidak } \\
\text { lengkap/jelas }\end{array}$ & 2.095 & $61,51 \%$ & $61,51 \%$ \\
$\begin{array}{l}\text { Penerima } \\
\text { pindah }\end{array}$ & 554 & $16,27 \%$ & $77,78 \%$ \\
$\begin{array}{l}\text { Ditolak } \\
\text { penerima }\end{array}$ & 475 & $13,95 \%$ & $91,73 \%$ \\
$\begin{array}{l}\text { Buntu } \\
\text { Rumah kosong }\end{array}$ & 95 & $2,79 \%$ & $94,52 \%$ \\
$\begin{array}{l}\text { Meninggal } \\
\text { dunia }\end{array}$ & 35 & $2,64 \%$ & $97,16 \%$ \\
Sebab kahar & 34 & $0,99 \%$ & $99,18 \%$ \\
\hline
\end{tabular}

\begin{tabular}{lccc}
\hline $\begin{array}{l}\text { Tidak } \\
\text { memenuhi } \\
\text { syarat pabean }\end{array}$ & 28 & $0,82 \%$ & $100 \%$ \\
\hline \multicolumn{1}{c}{ Total } & 3.406 & $100 \%$ & - \\
\hline
\end{tabular}

Dari 8 faktor permasalahan tersebut yang frekuensi paling besar yaitu pertama alamat yang tidak lengkap dengan frekuensi 2.095 item sebesar $61,51 \%$ dan yang kedua adalah penerima pindah dengan frekuensi 554 item dengan persentase sebesar $16,27 \%$. Berikut merupakan hasil pareto dari 8 permasalahan di atas dapat dilihat pada gambar 2.

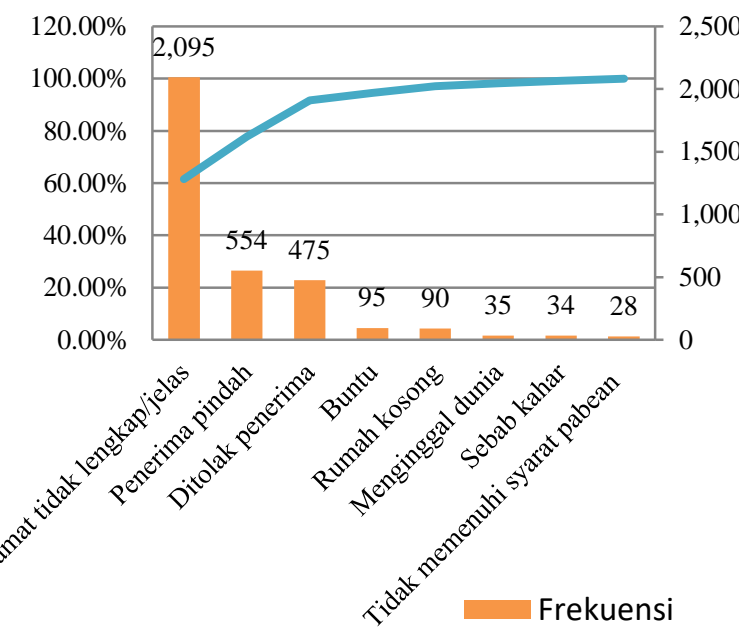

Gambar 2. Diagram pareto

Setelah membuat diagram Pareto maka dapat dilihat bahwa frekuensi kesalahan untuk alamat tidak lengkap dan penerima pindah, cukup tinggi dari permasalahan lainnya, frekuensi alamat tidak lengkap 2.095 item dengan persentase kesalahan $61,51 \%$ dan frekuensi penerima pindah 554 item dengan akumulasi persentase sebesar 77,78\%.

\section{PEMBAHASAN}

Analyze

Berdasarkan hasil penelitian di atas maka permasalahan utama gagal antar adalah alamat tidak lengkap dan penerima pindah. Setelah mengetahui permasalahan utama maka akan dilakukan analisis sebab dan akibat terjadinya permasalahan tersebut. Untuk menganalisis sebab dan akibat masalah tersebut akan menggunakan diagram sebab akibat (Cause and Effect Diagram).

Cause and Effect Diagram biasanya juga dikenal dengan nama diagram fishbone. Cause and Effect Diagram adalah sebuah teknik grafis yang digunakan untuk mengurutkan atau menghubungkan interaksi antara faktor-faktor 
yang berpengaruh dalam suatu proses. Diagram fishbone adalah suatu diagram yang menunjukkan sebab-sebab yang mengakibatkan suatu kejadian tertentu. Diagram ini berguna untuk menemukan dan menganalisa faktor-faktor yang berpengaruh secara signifikan di dalam menentukan karakteristik kualitas output kerja. Di samping itu juga diagram ini berguna untuk mencari penyebab yang sesungguhnya dari suatu masalah. Berikut merupakan diagram fishbone dalam ada dua permasalahan utama gagal antar yaitu alamat tidak lengkap dan penerima pindah.

1. Alamat Tidak Lengkap

Penyebab gagal antar alamat tidak lengkap menjadi kendala pengantar antara lain tidak mengikuti aturan penulisan menurut SOP, tidak adanya RT/RW, no telepon, nama jalan yang tidak jelas karena di daerah Mojokerto banyak sekali nama jalan yang sama sehingga menyulitkan pengantar untuk menemukan alamat penerima. Sehingga ketika petugas pengantar bertanya terhadap warga sekitar juga tidak mengetahui alamat yang dimaksud maka menyebabkan kiriman tersebut menjadi gagal antar. Berikut Gambar 2: Diagram Fishbone Alamat Tidak Lengkap.

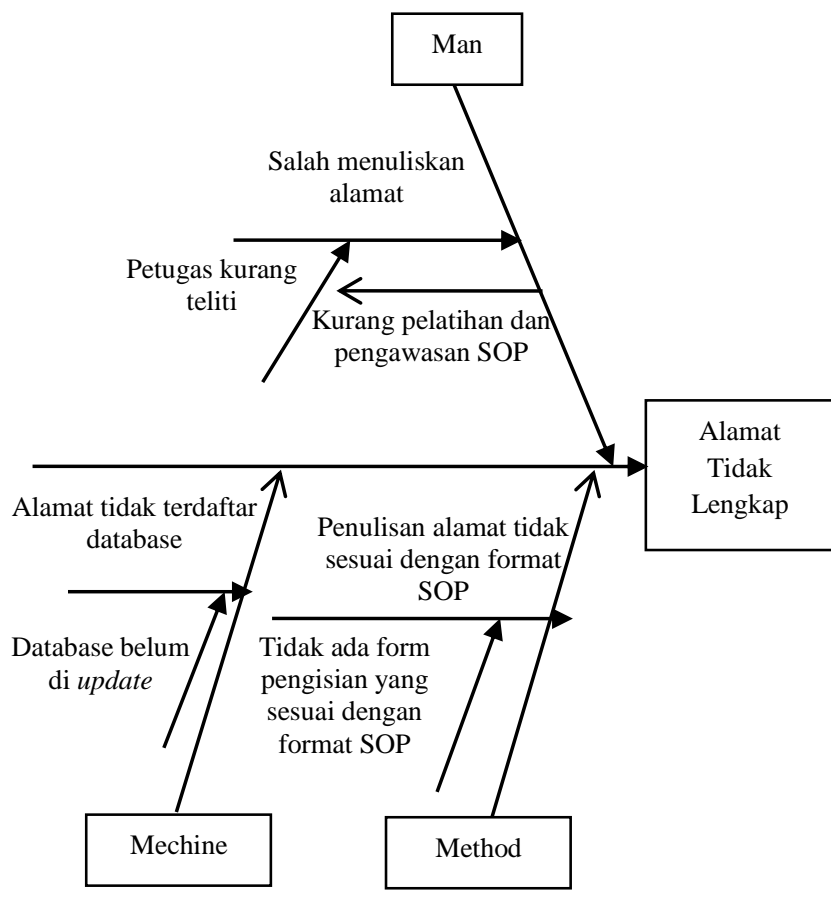

Gambar 3. Diagram fishbone alamat tidak lengkap.

Berikut penjelasan pada gambar 3 diagram fishbone gagal antar alamat tidak lengkap. Ada beberapa sebab dan akibat yang menyebabkan gagal antar kiriman paket dan surat dikarenakan alamat tidak lengkap antara lain: pertama, disebabkan oleh man yang kurang pelatihan dan pengawasan SOP menyebabkan petugas kurang teliti dalam memeriksa alamat yang mengakibatkan salah menuliskan alamat. Kedua, disebabkan oleh method tidak ada form pengisian yang sesuai dengan SOP sehingga mengakibatkan pengirim pada waktu penulisan alamat tidak sesuai dengan format SOP. Ketiga disebabkan karena mechine, database belum di update sehingga mengakibatkan alamat tidak terdaftar dalam database. Faktor-faktor inilah yang sering ditemukan dalam permasalahan ini yang akan mengakibatkan gagal antar.

2. Penerima Pindah

Biasanya warga Mojokerto sering berpindahpindah tempat seperti pindah rumah kontrak, kos ataupun pindah rumah ke daerah lainnya. Dari hasil penelusuran, pengantar mengirimkan paket kiriman ke alamat sesuai yang dituju akan tetapi penghuni alamat tersebut bukan penerima kiriman tersebut. Maka kiriman tidak dapat disampaikan kepada alamat tersebut sehingga terjadinya gagal antar kiriman, sehingga adanya konfirmasi ulang kepada penerima kiriman dengan dilakukan proses antar ulang. Berikut Gambar 3: Diagram Fishbone Penerima Pindah.

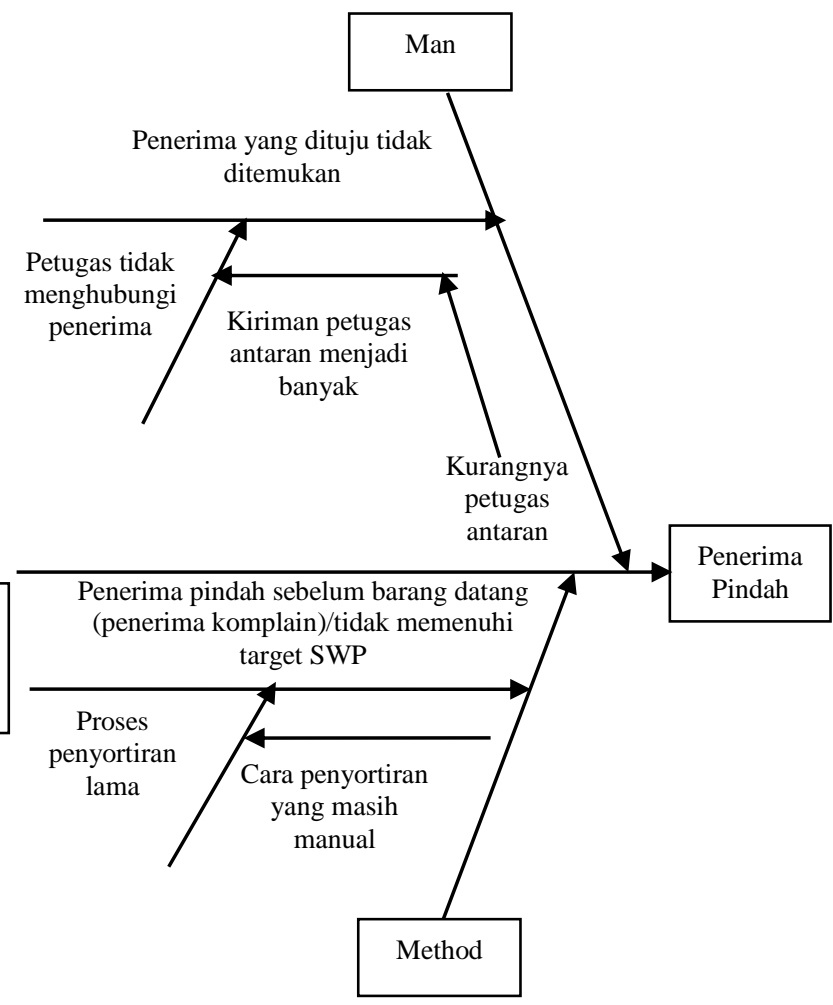

Gambar 4. Diagram fishbone penerima pindah

Berikut penjelasan pada gambar 4 diagram fishbone diatas ada beberapa sebab akibat yang menyebabkan gagal antar kiriman paket dan surat dikarenakan penerima pindah yaitu disebabkan karena man dan methode. Pertama man, kurangnya petugas antaran (kurir) menyebabkan kiriman petugas antaran menjadi banyak yang akan berpengaruh pada petugas karena petugas juga tidak menghubungi penerima terlebih dahulu sebelum mengirimkan kiriman paket atau surat 
sehingga mengakibatkan penerima yang dituju tidak ditemukan. Kedua method, cara penyortiran yang masih manual yang menyebabkan proses penyortiran lama sehingga pada saat waktu pengiriman yang diantar oleh pengantar dan tiba di alamat penerima tetapi penerima pindah sebelum barang datang maka tidak bisa memenuhi target SWP yang telah tetapkan. Faktor-faktor inilah yang sering ditemukan dalam permasalahan ini yang akan mengakibatkan gagal antar.

\section{Improve}

Untuk mengatasi permasalahan-permasalahan yang sudah dibahas maka diperlukan perbaikan untuk permasalahan tersebut. Perbaikan ini akan merekomendasikan menggunakan tindakan atau solusi dari $5 \mathrm{~W}+1 \mathrm{H}$, berarti bahwa dalam tahap ini peningkatan harus memutuskan apa (what) yang harus dicapai/apa yang menjadi target atau tujuan utama (berkaitan dengan target yang ditetapkan), alasan kegunaan (why) rencana tindakan itu harus dilakukan, dimana (where) tindakan itu akan diterapkan atau dilakukan, kapan (when) tindakan itu akan dilaksanakan, siapa (who) yang akan menjadi penanggung jawab dari rencana tindakan itu, bagaimana (how) melaksanakan rencana tindakan itu. Berikut tabel rekomendasi perbaikan $5 \mathrm{~W}+1 \mathrm{H}$ alamat tidak lengkap dan penerima pindah.

1. Alamat Tidak Lengkap

TABEL XII

REKOMENDASI 5W+1H ALAMAT TIDAK LENGKAP

\begin{tabular}{|c|c|}
\hline \multicolumn{2}{|r|}{ Alternatif Perbaikan } \\
\hline What & $\begin{array}{l}\text { Tujuan utama/target yang harus dicapai adalah } \\
\text { mengurangi gagal antar terutama status gagal antar } \\
\text { alamat yang tidak lengkap dan meningkatkan } \\
\text { keberhasilan SWP. }\end{array}$ \\
\hline Why & $\begin{array}{l}\text { Gagal antar karena alamat yang tidak lengkap perlu } \\
\text { dilakukan perbaikan karena beberapa alasan yaitu: } \\
\text { - Tercapainya target SWP yang sudah ditetapkan. } \\
\text { - Mengurangi penumpukan barang gagal antar. } \\
\text { - Tetap terjalinnya hubungan baik dengan } \\
\text { pelanggan } \\
\text { - Tidak mengganggu proses kerja yang ada di } \\
\text { lapangan }\end{array}$ \\
\hline Where & $\begin{array}{l}\text { Tindakan dalam masalah ini perlu dilakukan pada } \\
\text { setiap divisi. }\end{array}$ \\
\hline When & $\begin{array}{l}\text { Perbaikan dilakukan secepatnya dan dilakukan } \\
\text { secara periodik. Perbaikan diprioritaskan pada } \\
\text { bagian dengan tingkat permasalahan yang sering } \\
\text { terjadi }\end{array}$ \\
\hline Who & $\begin{array}{l}\text { Pihak yang bertanggung jawab atas masalah ini } \\
\text { adalah seluruh internal perusahaan khususnya } \\
\text { pegawai yang berada di lapangan baik divisi } \\
\text { pelayanan dan antaran. Kedua divisi ini harus } \\
\text { saling bekerja sama dalam mengatasi masalah ini. }\end{array}$ \\
\hline How & $\begin{array}{l}\text { Rencana dalam melaksanakan kegiatan perbaikan } \\
\text { dalam hal permasalahan ini sebagai berikut: }\end{array}$ \\
\hline & $\begin{array}{l}\text { - Dilakukan evaluasi terlebih dahulu. } \\
\text { - Manajer setiap divisi yang bersangkutan degan } \\
\text { masalah ini harus memberikan pelatihan SOP } \\
\text { dan mengawasi petugas lebih teliti, cermat, dan }\end{array}$ \\
\hline
\end{tabular}

harus mengontrol semua pekerjaan yang dilakukan petugas. Supaya proses ini berjalan dengan baik.

- Memperbaiki SOP penulisan alamat asal dan tujuan yang baik dan benar.

- Dilakukan perbaruan database secara berkala

2. Penerima Pindah

TABEL XIII

REKOMENDASI 5W+1H PENERIMA PINDAH

\begin{tabular}{|c|c|}
\hline & Alternatif Perbaikan \\
\hline What & $\begin{array}{l}\text { Tujuan utama/target yang harus dicapai adalah } \\
\text { menguragi gagal antar terutama status gagal } \\
\text { antar penerima pindah, tidak terjadi } \\
\text { keterlambatan barang, diterima oleh penerima } \\
\text { yang benar dan meningkatkan keberhasilan } \\
\text { SWP. }\end{array}$ \\
\hline \multirow[t]{4}{*}{ Why } & $\begin{array}{l}\text { Gagal antar karena penerima pindah perlu } \\
\text { dilakukan perbaikan karena beberapa alasan } \\
\text { yaitu: }\end{array}$ \\
\hline & $\begin{array}{l}\text { - Tercapainya target SWP yang sudah } \\
\text { ditetapkan. }\end{array}$ \\
\hline & $\begin{array}{l}\text { - Tetap terjalinnya hubungan baik dengan } \\
\text { customer. }\end{array}$ \\
\hline & $\begin{array}{l}\text { - Tidak menggagu proses kerja yang ada } \\
\text { dilapangan. }\end{array}$ \\
\hline Where & $\begin{array}{l}\text { - Tidak terjadinya complaint dari penerima. } \\
\text { Tidakan dalam masalah ini perlu dilakukan } \\
\text { pada setiap divisi khususnya pada divisi } \\
\text { operasional bagian antaran. }\end{array}$ \\
\hline When & $\begin{array}{l}\text { Perbaikan dilakukan secepatnya dan dilakukan } \\
\text { secara periodik. }\end{array}$ \\
\hline Who & $\begin{array}{l}\text { Pihak yang bertanggung jawab atas masalah ini } \\
\text { adalah divisi operasional bagian antaran. }\end{array}$ \\
\hline \multirow[t]{5}{*}{ How } & $\begin{array}{l}\text { Rencana dalam melaksanakan kegiatan } \\
\text { perbaikan dalam hal permasalahan ini sebagai } \\
\text { berikut: }\end{array}$ \\
\hline & - Dilakukan evaluasi terlebih dahulu. \\
\hline & $\begin{array}{l}\text { - Sebelum barang diantar maka petugas harus } \\
\text { menghubungi penerima terlebih dahulu supaya } \\
\text { tidak terjadi gagal antar. }\end{array}$ \\
\hline & $\begin{array}{l}\text { - Melakukan perbaikan pada penyortiran supaya } \\
\text { cepat dengan menggunakan mesin otomatis. }\end{array}$ \\
\hline & $\begin{array}{l}\text { - Menambah petugas antaran supaya paket bisa } \\
\text { dikirimkan lebih cepat. }\end{array}$ \\
\hline
\end{tabular}

\section{KESIMPULAN}

Metode DMAIC dalam hal permasalahan ini maka metode tersebut sangat cocok dalam membantu memperbaiki dan meminimalisirkan permasalahan ini karena bias menemukan akarakar penyebab permasalahan. Sehingga bias tahu cara memperbaiki masalah tersebut.

Root cause yang pertama sebesar 61,51\% adalah status gagal antar yang disebabkan oleh alamat tidak lengkap/jelas, selanjutnya dengan analisis menggunakan metode diagram pareto bahwa proses gagal antar yang dominan terjadi pada alamat tidak jelas sebesar 2.095 item. Root cause yang kedua adalah penerima pindah dengan akumulasi persentase sebesar 77,78 \% dengan frekuensi 554 item adalah status gagal antar yang disebabkan oleh penerima pindah.

Jadi secara garis besar permasalahan ini disebabkan karena manusia atau pekerja dan metode. Untuk itu maka dilakukan peningkatan 
SDM dengan melakukan pelatihan, pengawasan dan lainnya serta memperbaiki metode. Sehingga dapat membantu meminimalisirkan permasalahan gagal antar.

\section{REFERENSI}

[1] Evan, R, James \& Lindsay, M, William. An Introduction to Six Sigma and Process Improvement. South Western: Singapore, 2007.

[2] Shankar, Rama. Process Improvement Using Six Sigma: A DMAIC Guide. ASQ: United State of America, 2009.

[3] Awasthi, Anjali, Grzybowska, Katarzyna, Handbook of Research on Interdisciplinary Approaches to Decision Making for Sustainables Supplay Chains, United state of America: IGI Global, 2019.

[4] Siswoyo. D. Sriyono, Sistarani Meutia. Manajemen Teknik. Yogyakarta: CV Budi Utama, 2020.

[5] Sunarto, WN. Heru Santoso. Buku Saku Analisis Pareto. Surabaya: Poltekkes Kemenkes Surabaya, 2020.

[6] Gaspersz,V. Pedoman Implementasi Program Six Sigma Terintegrasi dengan ISO 9001: 2000, MBNQA, dan HACCP. Bogor: Gramedia Pustaka Umum, 2002.

[7] Kurniasih Dewi. Failure in Safety Systems. Metode Analisis Kecelakaan Kerja. Sidoarjo: Zifatama Jawara, 2020. 